\title{
Variation in Vertebral Averages for Year-classes of Atlantic Cod, Gadus morhua, on Flemish Cap
}

\author{
W. H. Lear and R. Wells \\ Department of Fisheries and Oceans, Research and Resource Services \\ P. O. Box 5667, St. John's, Newfoundland, Canada A1C 5X1 \\ and \\ W. Templeman \\ J. L. Paton Chair of Marine Biology and Fisheries \\ Memorial University of Newfoundland \\ St. John's, Newfoundland, Canada A1C 5S7
}

\begin{abstract}
Analysis of the average numbers of vertebrae in 21 year-classes of Atlantic cod, Gadus morhua L., produced on Flemish Cap during 1940-66, indicated minimal variation in vertebral averages among year-classes. Although variances of the vertebral frequencies for these year-classes were found to be heterogeneous and their means significantly different, the variances of 17 vertebral frequencies were homogeneous and their means, ranging from 54.37 to 54.78 , did not differ significantly. It was concluded that the factors responsible for determining the vertebral numbers in cod on Flemish Cap are not subject to great variation.
\end{abstract}

\section{Introduction}

The discreteness of the cod population on Flemish Cap has been demonstrated by a variety of techniques, including meristic characters, tagging studies, parasite incidence, biochemical criteria, and growth differences.

Templeman (1962) indicated that the average number of vertebrae in cod on Flemish Cap was slightly lower than in cod on the neighboring northeast corner of Grand Bank. Stanek (MS 1968) found that cod on Flemish Cap possessed, on the average, one additional fin ray in the second dorsal fin than did cod on the eastern edge of Grand Bank. Lear et al. (MS 1979) reported that the variances of the vertebral frequencies for the cod year-classes of 1956, 1957, 1958 and 1959 on Flemish Cap were in every case significantly less than those for the corresponding yearclasses on Grand Bank.

From Canadian tagging of cod on Flemish Cap in 1964 , only 1 of 98 recaptures in 1964 and 6 of 40 recaptures after 1964 were taken west of Flemish Channel $(>1,000 \mathrm{~m}$ deep) which separates Flemish Cap from eastern Grand Bank (Templeman, 1979). From USSR tagging of cod on Flemish Cap during 1961-66, all recaptures were reported from that bank (Konstantinov, 1970). Extensive Canadian tagging of cod mainly in coastal Newfoundland areas during 1954-55 and in both coastal and offshore areas of Labrador and Newfoundland during 1962-66 resulted in more than 20,000 recaptures, of which only four tagged in the latter period were reported to have been recaptured on Flemish Cap (Templeman, 1974, 1979). Also, there were no records of tagged cod having migrated to Flemish Cap from other areas of Subareas 2 and 3, based on 35,000 cod tagged by USSR during 1960-66 (Konstantinov, MS 1967).

Templeman et al. (1957) found no evidence of the nematode, Terranova decipiens, in the fillets of cod from Flemish Cap, although they were present in about $2 \%$ of the cod from northeastern Grand Bank. There was also no infection of cod by the parasitic copepod, Lernaeocera branchialis, on Flemish Cap, whereas $0.6-2.3 \%$ of cod from the neighboring Grand Bank were infected (Templeman et al., 1976). Postolaky (1962) found that plerocercoids of the cestode, Pyramicocephalus phocarum, were absent in cod from Flemish Cap but present in cod from southern Labrador and northern Grand Bank (10 and 4\% infestation respectively).

Jamieson (1975) found highly significant differences in transferrin allele frequencies in blood sera of cod from Flemish Cap and those of northeastern Grand Bank. Likewise, Cross and Payne (1978) showed that the cod population on Flemish Cap was distinct from those on other parts of the continental shelf, there being a significant difference in allele frequencies at the PGI-2 locus (skeletal muscle phosphoglucose isomerase). Because of the genetic difference between the cod population on Flemish Cap and those on the 
North American shelf, they suggested that the Flemish Cap population may have persisted in isolation since the last glaciation.

Thompson (1943) reported that the average number of circuli in the first annulus of scales from a small sample of cod from Flemish Cap (12.4) was greater than that in cod of the northern Grand Bank (9.6). Stanek (MS 1968) reported that, although growth of cod up to age 5 on Flemish Cap was similar to that on northern Grand Bank, the average length increments for ages over 5 years were lower on Flemish Cap than on neighboring areas of Grand Bank.

Considering the apparent discreteness of the cod population on Flemish Cap, the purpose of this paper is to investigate the variation in vertebral averages among year-classes of 1939-67. Available water temperature data are utilized in an attempt to determine if the variation in vertebral averages can be explained by this environmental factor.

\section{Materials and Methods}

During 1949-51, 1961-62, 1964 and 1968, several cod samples, each containing more than 100 specimens, were collected from otter-trawl catches on Flemish Cap by research vessels of the St. John's Biological Station. Examination of the material in the laboratory included extraction of the otoliths for age determination and removal of the flesh from the skeletons to facilitate counting the number of vertebrae. All counts include the urostylar half-vertebra as a vertebra. To eliminate errors caused by inaccurate ageing of cod older than 10 years, only the vertebral numbers for fish aged 1 to 10 years were used in the analysis. Specimens with fused vertebrae were not included in the calculation of vertebral averages, which are listed by year-classes (1939-67) in Table 1. Year-class data represented by less than five specimens $(1939,1951$, 1955 and 1967 year-classes) were omitted from the analyses, because such small sample sizes may not be truly representative of the population and because the critical values of the Brown-Forsythe statistic $\left(F^{*}\right)$ and the Welch statistic (W) are only reasonably valid for more than five observations (Brown and Forsythe, 1974a).

All available water temperature observations in March, April and May for four grids covering the Flemish Cap area (Fig. 1) and in July for a station on the center of the bank at depth levels of $0,10,20,30,50,75$, 100 and $125 \mathrm{~m}$ were obtained from the Marine Environmental Data Service, Ottawa. Unfortunately, the time series was limited to $1953-65$ and the observations sporadic in some months and grids.

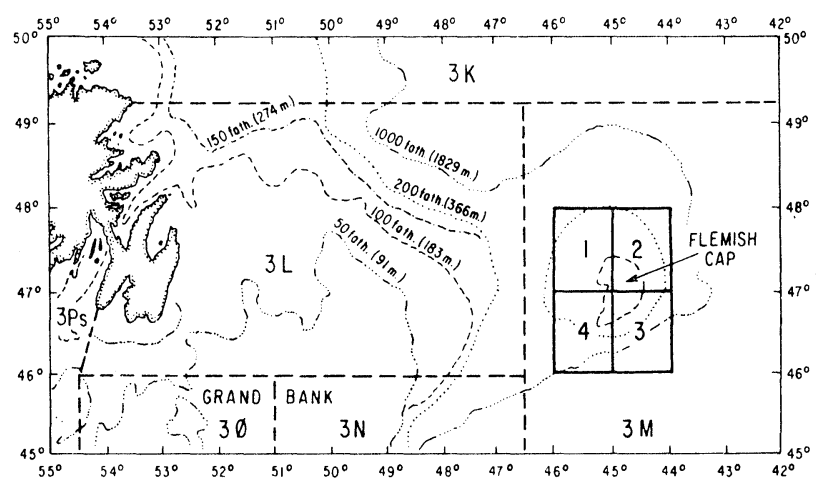

Fig. 1. Area map showing the location of Flemish Cap and the four grids on Flemish Cap from which temperature data were analyzed.

\section{Results}

Levene's test for homogeneity of variances (Brown and Forsythe, 1974b), performed on the vertebral data for 21 year-classes of cod produced during 1940-66 (Table 1), indicated that the variances of the vertebral averages were heterogeneous $(P<0.01)$. The $F$ statistic from the one-way analysis of variance (ANOVA) is sensitive to a lack of homogeneity of within-group variances, and consequently the modified $F$-statistic $\left(F^{\star}\right)$ which does not assume equality of variances (Brown and Forsythe, 1974a) was calculated using the Biomedical Computer Program (BMDP7D) (Dixon and Brown, 1979). Also, the Welch statistic (W) (Welch, 1951) was calculated using the same program. Both the $\mathrm{F}^{*}$-statistic and the $\mathrm{W}$-statistic indicated significant differences in vertebral averages for the 21 year-classes $(P<0.01)$. However, multiple comparison tests (Brown and Forsythe, 1974C) failed to show significant differences at $P=0.05$. The $F^{*}$-statistic was calculated for various groups of year-classes to determine those which did not differ significantly. The vertebral averages for 17 year-classes (1940-44, 1946-47, 1953-54, 1956-59, 1961-62, 1964-65) had homogeneous variances according to Levene's test and did not differ significantly $(P<0.01)$ according to the $F^{*}$ statistic (Table 1).

Fused vertebrae occurred occasionally in the samples (Table 1), the overall average being $1.95 \%$, but there was no significant difference among yearclasses.

An attempt was made to investigate the relationship between cod vertebral averages and water temperatures on Flemish Cap. In the absence of sufficient data for March, the month of peak spawning, available observations in April and May for four grids covering the bank and slopes (Fig. 1) were examined. The data for grids 1 and 2 were too sparse for regression analyses. For grid 3 in April 1953-54, 1956-59, 1961-65 and in May 1953, 1956-60, 1963-65, the 
TABLE 1. Vertebral data for cod year-classes in samples collected on Flemish Cap during 1940-66. Analysis of variance ( $F^{*}$-statistic) indicated that the asterisked $\left(^{*}\right)$ vertebral means did not differ significantly at $P=0.01$.

\begin{tabular}{|c|c|c|c|c|c|c|}
\hline \multirow{2}{*}{$\begin{array}{l}\text { Year- } \\
\text { class }\end{array}$} & \multirow{2}{*}{$\begin{array}{l}\text { Number } \\
\text { sampled }\end{array}$} & \multicolumn{2}{|c|}{ Fused vertebrae } & \multicolumn{3}{|c|}{ Vertebral counts } \\
\hline & & No. & $\%$ & No. & Mean & S.D. \\
\hline 1940 & 9 & 0 & 0.0 & 9 & $54.556^{\star}$ & 0.527 \\
\hline 1941 & 43 & 2 & 4.7 & 41 & $54.366^{\star}$ & 0.698 \\
\hline 1942 & 37 & 0 & 0.0 & 37 & $54.541^{\star}$ & 0.691 \\
\hline 1943 & $153^{\circ}$ & 2 & 1.3 & 151 & $54.669^{\star}$ & 0.719 \\
\hline 1944 & 72 & 3 & 4.2 & 69 & $54.667^{\star}$ & 0.741 \\
\hline 1945 & 15 & 0 & 0.0 & 15 & 55.000 & 0.926 \\
\hline 1946 & 163 & 5 & 3.1 & 158 & $54.684^{\star}$ & 0.669 \\
\hline 1947 & 36 & 0 & 0.0 & 36 & $54.778^{\star}$ & 0.722 \\
\hline 1953 & 43 & 0 & 0.0 & 43 & $54.721^{\star}$ & 0.701 \\
\hline 1954 & 52 & 0 & 0.0 & 52 & $54.673^{*}$ & 0.810 \\
\hline 1956 & 87 & 2 & 2.3 & 85 & $54.753^{\star}$ & 0.739 \\
\hline 1957 & 124 & 3 & 2.4 & 121 & $54.736^{\star}$ & 0.716 \\
\hline 1958 & 208 & 5 & 2.4 & 203 & $54.522^{\star}$ & 0.733 \\
\hline 1959 & 57 & 1 & 1.8 & 56 & $54.518^{\star}$ & 0.763 \\
\hline 1960 & 72 & 1 & 1.4 & 71 & 54.324 & 0.692 \\
\hline 1961 & 18 & 1 & 5.6 & 17 & $54.529^{\star}$ & 0.515 \\
\hline 1962 & 94 & 2 & 2.1 & 92 & $54.576^{\star}$ & 0.667 \\
\hline 1963 & 148 & 3 & 2.0 & 145 & 54.869 & 0.604 \\
\hline 1964 & 37 & 0 & 0.0 & 37 & $54.622^{*}$ & 0.794 \\
\hline 1965 & 170 & 2 & 1.2 & 168 & $54.673^{*}$ & 0.730 \\
\hline 1966 & 22 & 0 & 0.0 & 22 & 54.046 & 0.653 \\
\hline $1939^{a}$ & 2 & 0 & 0.0 & 2 & 54.500 & 0.707 \\
\hline $1951^{a}$ & 2 & 0 & 0.0 & 2 & 55.000 & 0.000 \\
\hline $1955^{a}$ & 4 & 0 & 0.0 & 4 & 55.500 & 1.000 \\
\hline $1967^{\mathrm{a}}$ & 1 & 0 & 0.0 & 1 & 54.000 & - \\
\hline
\end{tabular}

${ }^{a}$ These four year-classes not included in the analysis.

temperature $\left({ }^{\circ} \mathrm{C}\right)$ at each depth level of $0,10,20,30,50$, $75,100,125 \mathrm{~m}$ and the average of $0-125 \mathrm{~m}$ were regressed against the vertebral averages of the corresponding year-classes. No significant correlations were found. Similar regressions were undertaken for grid 4 in April 1954, 1956-59, 1961-64 and in May 1953, 1956-60, 1963-64, with no significant correlations.

\section{Discussion}

Various researchers have demonstrated experimentally that low and high temperatures during late egg and early larval developmental stages tend to produce higher vertebral numbers in fishes than intermediate temperatures: Tåning $(1944,1952)$ for sea trout, Salmo trutta; Lindsey (1954) for paradise fish, Macropodus opercularis; and Molander and MolanderSwedmark (1957) for plaice, Pleuronectes platessa. However, the higher vertebral numbers caused by high temperatures are not always observed under experimental conditions and not as a rule evident in nature. Fahy (1972, 1976) found that embryos of Fundulus majalis reared continuously in temperatures regimes ranging from $13^{\circ}$ to $32^{\circ} \mathrm{C}$ developed vertebral numbers which were on the average inversely related to temperature. Dannevig (1950) reported, for plaice eggs developed at temperatures of $4.9^{\circ}$ and $5.4^{\circ} \mathrm{C}$, that the average number of vertebrae in the resultant larvae was
0.4 lower at the higher temperature. Tåning (1952), for sea trout reared at temperatures of $3^{\circ}$ to $6^{\circ} \mathrm{C}$, stated that the phenocritical period in which the number of vertebrae was established occurred within 13-23 days after fertilization and long before hatching of the egg. $\mathrm{He}$ also noted that there was a short supersensitive period of about 20 degree days (i.e. 145-165D ${ }^{\circ}$ ) when the number of vertebrae was extremely sensitive to a change in temperature.

Under natural conditions, Clark and Vladykov (1960) noted that there was an inverse relationship between average number of vertebrae in haddock, Melanogrammus aeglefinus, and surface water temperature at spawning time for both the Northeast and Northwest Atlantic stocks. They suggested that a single vertebral number-temperature relationship applied to the species throughout its range. Brander (1979) indicated that there was an inverse relationship between surface water temperature during early development and mean vertebral number for cod populations throughout the North Atlantic. He also found that the vertebral averages for different year-classes of cod in the North Sea showed some dependence on water temperature, and suggested that year-class should be taken into account, where possible, when seeking evidence of stock separation.

Cod on Flemish Cap spawn mainly during March but some spawning occurs in February, April and May (Templeman, 1976). Larval stages have been taken over the central part of the bank in April (Serebryakov, 1965). It is evident, therefore, that late egg and early larval stages, during which the numbers of vertebrae are determined, are present on Flemish Cap at least from March to June but mainly in March-April. Possible reasons for the lack of correlation of the year-class vertebral averages with April-May temperatures are the year-to-year variation in the dates and locations of the temperature observations, the large area of each grid for which the temperature data were averaged, including stations south of the bank not inhabited by eggs and larvae, and consequently the lack of coincidence of the temperature data with the actual temperatures during the short phenocritical period when vertebral numbers are established. Also, there were no temperature data for some year-classes, particularly that of 1945 which had the highest vertebral average, that of 1966 which had the lowest average, and that of 1941 which also had a low average.

Temperature conditions on Flemish Cap are probably relatively stable, as evidenced from temperature profiles in late July (1953-66) for a station on the center of the bank (Table 2). This may explain the general lack of great variability in cod vertebral numbers. Another possible explanation may be the isolation of this population which may have less genetic variability than 
TABLE 2. Temperature observations $\left({ }^{\circ} \mathrm{C}\right)$ at various depths on the central part of Flemish Cap $\left(47^{\circ} 00^{\prime} \mathrm{N}, 45^{\circ} 00^{\prime} \mathrm{W}\right)$ in late July-early August, $1953-54$ and $1956-66$.

\begin{tabular}{|c|c|c|c|c|c|c|c|c|c|c|c|c|c|}
\hline $\begin{array}{l}\text { Depth } \\
(\mathrm{m})\end{array}$ & $\begin{array}{c}26 \mathrm{Jul} \\
1953\end{array}$ & $\begin{array}{c}26 \mathrm{Jul} \\
1954\end{array}$ & $\begin{array}{c}1 \text { Aug } \\
1956\end{array}$ & $\begin{array}{c}1 \text { Aug } \\
1957\end{array}$ & $\begin{array}{c}29 \mathrm{Jul} \\
1958\end{array}$ & $\begin{array}{c}27 \text { Jul } \\
1959\end{array}$ & $\begin{array}{c}25 \mathrm{Jul} \\
1960\end{array}$ & $\begin{array}{c}25 \mathrm{Jul} \\
1961\end{array}$ & $\begin{array}{c}26 \mathrm{Jul} \\
1962\end{array}$ & $\begin{array}{c}29 \mathrm{Jul} \\
1963\end{array}$ & $\begin{array}{c}25 \mathrm{Jul} \\
1964\end{array}$ & $\begin{array}{c}24 \mathrm{Jul} \\
1965\end{array}$ & $\begin{array}{c}27 \mathrm{Jul} \\
1966\end{array}$ \\
\hline 0 & 11.99 & 13.58 & 11.59 & 11.38 & 10.54 & 11.30 & 13.10 & 12.20 & 11.30 & 10.70 & 12.70 & 11.80 & 15.70 \\
\hline 10 & 11.43 & 12.28 & 11.04 & 11.32 & 10.45 & $: 1.19$ & 13.30 & 11.87 & 11.12 & 10.69 & 12.68 & 11.80 & 12.58 \\
\hline 20 & 10.86 & 10.98 & 10.49 & 11.26 & 10.36 & 9.94 & 12.80 & 11.63 & 10.54 & 10.67 & 12.58 & 9.70 & 9.04 \\
\hline 30 & 9.72 & 9.24 & 9.23 & 9.95 & 10.22 & 8.15 & 9.60 & 10.36 & 9.85 & 6.59 & 7.03 & 8.40 & 7.81 \\
\hline 50 & 6.29 & 4.90 & 5.29 & 4.82 & 9.81 & 4.93 & 5.80 & 3.83 & 6.58 & 4.76 & 4.81 & 5.40 & 5.82 \\
\hline 75 & 4.04 & 4.04 & 3.96 & 3.71 & 4.98 & 3.25 & 3.80 & 3.49 & 6.65 & 3.76 & 4.40 & 4.30 & 5.02 \\
\hline 100 & 4.75 & 3.74 & 3.64 & 3.08 & 4.59 & 2.85 & 3.50 & 3.44 & 4.13 & 3.39 & 3.94 & 4.20 & 4.59 \\
\hline 125 & 3.93 & 3.80 & 3.48 & 3.05 & 4.20 & 2.87 & 3.45 & 3.49 & 4.64 & 3.22 & 3.80 & 4.10 & 4.50 \\
\hline 150 & 3.12 & - 3.86 & 3.15 & 3.01 & 3.81 & 2.89 & 3.40 & 3.54 & 4.14 & 3.57 & 3.71 & 4.00 & 4.41 \\
\hline Bottom & $\begin{array}{c}3.02 \\
(153 \mathrm{~m})\end{array}$ & $\begin{array}{c}3.87 \\
(154 \mathrm{~m})\end{array}$ & $\begin{array}{c}3.25 \\
(160 \mathrm{~m})\end{array}$ & $\begin{array}{c}3.01 \\
(152 \mathrm{~m})\end{array}$ & $\begin{array}{c}3.72 \\
(156 \mathrm{~m})\end{array}$ & $\begin{array}{c}2.90 \\
(158 \mathrm{~m})\end{array}$ & $\begin{array}{c}3.40 \\
(160 \mathrm{~m})\end{array}$ & $\begin{array}{c}3.56 \\
(158 \mathrm{~m})\end{array}$ & $\begin{array}{c}4.05 \\
(155 \mathrm{~m})\end{array}$ & $\begin{array}{c}3.69 \\
(155 \mathrm{~m})\end{array}$ & $\begin{array}{c}3.71 \\
(155 \mathrm{~m})\end{array}$ & $\begin{array}{c}4.00 \\
(155 \mathrm{~m})\end{array}$ & $\begin{array}{c}4.41 \\
(150 \mathrm{~m})\end{array}$ \\
\hline Av. $0-150$ & 7.35 & 7.38 & 6.87 & 6.84 & 7.66 & 6.37 & 7.64 & 7.09 & 7.66 & 6.37 & 7.29 & 7.08 & 7.72 \\
\hline
\end{tabular}

other larger cod populations, such as those of the Labrador-eastern Newfoundland stock complex.

\section{Acknowledgements}

Thanks are extended to Mr Jean Gagnon of the Marine Environmental Data Service, Ottawa, who provided computer printouts of the temperature data for Flemish Cap, and to Mr Don Stansbury who provided statistical advice and assisted with computer programming.

\section{References}

BRANDER, K. 1979. The relationship between vertebral number and water temperature in cod. ICES J. Cons., 38: 286-292.

BROWN, M. B., and A. B. FORSYTHE. 1974a. The small sample behaviours of some statistics which test the equality of several means. Technometrics 16(1): 129-132.

1974b. Robust tests for the equality of variances. J. Amer. Stat. Assoc., 69: 364-367.

1974c. The ANOVA and multiple comparisons for data with heterogeneous variances. Biometrics, 30: 719-724.

CLARK, J. R., and V. D. VLADYKOV. 1960. Definition of haddock stocks of the northwestern Atlantic. Fish. Bull.,U.S.., 60: 283-296.

CROSS, T. F., and R. H. PAYNE. 1978. Geographic variation in Atlantic cod (Gadus morhua) off eastern North America: a biochemical systematics approach. J. Fish. Res. Bd. Canada, 35: 117-123.

DANNEVIG, A. 1950. The influence of the environment on number of vertebrae in plaice. Fiskeridir. Skr. (Havunders.) 9(9): $6 \mathrm{p}$.

DIXON, W. J., and M. B. BROWN (Ed.) 1979. Biomedical computer programs, P-series. Univ. of California Press, Los Angeles, $880 \mathrm{p}$.

FAHY, W. E. 1972. Influence of temperature change on number of vertebrae and caudal fin rays in Fundulus majalis (Walbaum). ICES J. Cons.,34: 217-231.

1976. The morphological time of fixation of the total number of vertebrae in Fundulus majalis (Walbaum). ICES J. Cons., 36: 243250.

JAMIESON, A. 1975. Enzyme types of Atlantic cod stocks on the North American banks. In: Isoenzymes IV, Genetics and Evolution (C. L. Markert, ed), Acad. Press, San Francisco, p. 491-515.

KONSTANTINOV, K. G. MS 1967. Results of cod tagging off Labrador (Subarea 2) and Newfoundland (Subarea 3). ICNAF Res. Doc., No. 49, Serial No. 1837.

1970. On the appropriateness of the Flemish Cap cod stock for experimental regulation of a fishery. ICNAF Redbook 1970, Part III: 49-55.
LEAR, W. H., R. WELLS, and W. TEMPLEMAN. MS 1979. The discreteness of the Flemish Cap cod stock. ICNAFRes. Doc., No. 76, Serial No. 5418.

LINDSEY, C. C. 1954. Temperature-controlled meristic variations in the paradise fish, Marcropodus opercularis (L.). Can. J. Zool., 32: 87-98.

MOLANDER, A. R., and M. MOLANDER-SWEDMARK. 1957. Experimental investigations on variation in plaice (Pleuronectes platessa Linné). Rep. Inst. Mar. Res., Lysekil, (Biol.), No. 7, 45 p.

POSTOLAKY, A. I. 1962. Biology of the Labrador and Newfoundland cod. In: Soviet Fisheries Investigations in the Northwest Atlantic, VNIRO-PINRO, Moscow, p. 338-348. (Transl. for U. S. Dep. Int and Nat. Sci Found., Washington, D. C., by Israel Prog. Sci. Transl., 1963)

SEREBRYAKOV, V. P. 1965. Some results of Soviet research work on ichthyoplankton in the Northwest Atlantic: eggs and larvae of cod. ICNAF Spec. Publ., No. 6: 425-433.

STANEK, E. MS 1968. The number of rays in the second dorsal fin and the number of vertebrae in cod from Labrador, Newfoundland and Nova Scotia. ICNAF Res. Doc., No. 71, Serial No. 2058.

TANING, A. V. 1944. Experiments on meristics and other characters in fishes. I. On the influence of temperature on some meristic characters in sea-trout and the fixation-period of these characters. Medd. Danm. Fisk.-og Havunders. N. S., 11(3): 1-66.

1952. Experimental study of meristic characters in fishes. Biol. Rev., 27: 169-193.

TEMPLEMAN, W. 1962. Division of cod stocks in the Northwest Atlantic. ICNAF Redbook 1962, Part III: 79-123.

1974. Migrations and intermingling of Atlantic cod (Gadus morhua) stocks of the Newfoundland area. J. Fish. Res. Bd. Canada, 31: 1073-1092.

1976. Biological and oceanographic background of Flemish Cap as an area for research on the reasons for year-class success and failure in cod and redfish. ICNAF Res. Bull., No. 12: 91-117.

1979. Migration and intermingling of stocks of Atlantic cod Gadus morhua, of the Newfoundland and adjacent areas from tagging in 1962-66. ICNAF Res. Bull., No. 14: 5-50.

TEMPLEMAN, W., V. M. HODDER, and A. M. FLEMING. 1976. Infection of lumpfish (Cyclopterus lumpus) with larvae and of Atlantic cod (Gadus morhua) with adults of the copepod, Lernaeocera branchialis, in and adjacent to the Newfoundland area, and inferences therefrom on inshore-offshore migrations of cod. J. Fish. Res. Bd. Canada, 33: 711-731.

TEMPLEMAN, W., H. J. SQUIRES, and A. M. FLEMING. 1957. Nematodes in the fillets of cod and other fishes in Newfoundland and neighbouring areas. J. Fish. Res. Bd. Canada, 14: 831-897.

THOMPSON, H. 1943. A biological and economic study of cod (Gadus callarias L.) in the Newfoundland area. Nfld. Dep. Nat. Resour., Fish. Bull., No. 14, $160 \mathrm{p}$.

WELCH, B. L. 1951. On the comparison of several mean values: an alternative approach. Biometrika, 38: 330-336. 